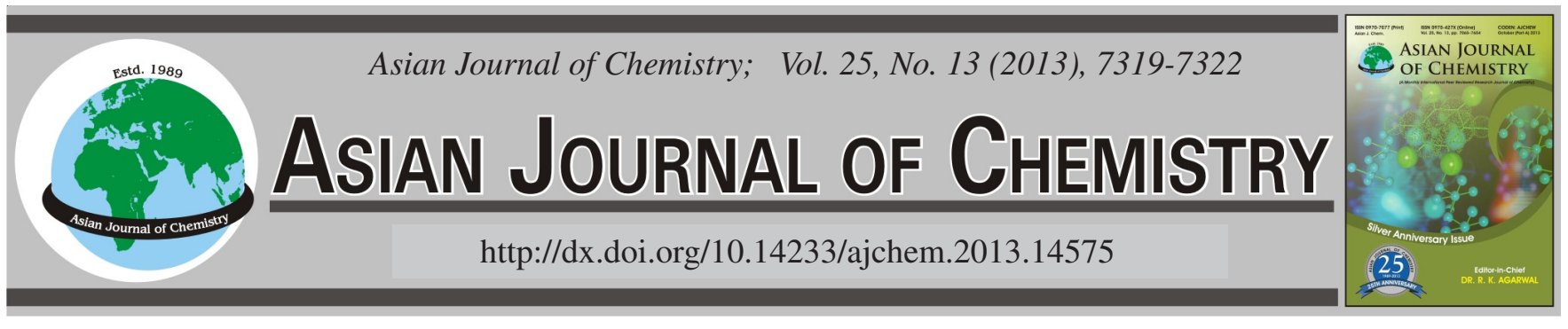

\title{
Adsorption Thermodynamic Characteristics of Cry1Ab Toxin from Bacillus thuringiensis in Chinese Latosol
}

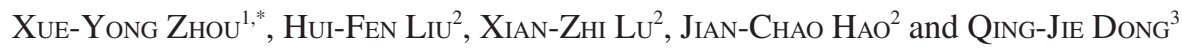

${ }^{1}$ Tianjin Engineering and Technology Research Center of Agricultural Products Processing, Department of Food Science, Tianjin Agricultural University, Tianjin 300384, P.R. China

${ }^{2}$ Department of Agronomy, Tianjin Agricultural University, Tianjin 300384, P.R. China

${ }^{3}$ College of Chemistry and Chemical Engineering, Tianjin University of Technology, Tianjin 300384, P.R. China

*Corresponding author: Te./Fax: +86 22 23782596; E-mail: zhouxueyongts@163.com

\begin{abstract}
The adsorption thermodynamics of Cry1 Ab toxin of Bacillus thuringiensis (Bt) in Chinese latosol was studied. The adsorption isotherms of Cry1 Ab toxin followed Langmuir equation $\left(\mathrm{R}^{2}>0.98\right)$ and the curves belonged to $\mathrm{L}$ type. The adsorption increased with the increased temperature and the maximum adsorption amount between 283 and $313 \mathrm{~K}$ ranged from $4.50 \times 10^{-6}$ to $7.55 \times 10^{-6} \mathrm{~mol} \mathrm{~g}^{-1}$. The results show that the environmental risk of Cry1 Ab toxin in Chinese latosol probably enhances if temperature increases. The adsorption of Cry1 $\mathrm{Ab}$ toxin in Chinese latosol was a spontaneous, endothermic and entropy-increasing process. The separation factor ranged from 0.1865 to 0.4682 , indicating that the adsorption of Cry $1 \mathrm{Ab}$ toxin in Chinese latosol was favourable. The adsorption energy for Cry $1 \mathrm{Ab}$ toxin ranged from 8 to $16 \mathrm{~kJ} \mathrm{~mol}^{-1}$, indicating that it was an ion-exchange mechanism.
\end{abstract}

Key Words: Bacillus thuringiensis, Toxin, Latosol, Adsorption, Thermodynamics.

\section{INTRODUCTION}

Since GM crops first commercialized in 1996, Bacillus thuringiensis (Bt) crops became an integral component of pest management practices in many countries ${ }^{1,2}$. The planting of GM crops has consistently increased by $10 \%$ or more each year worldwide. Transgenic plants encoding Cry1Ab toxins release these proteins into the soil through root exudates during the vegetative period ${ }^{3,4}$ and through the incorporation of plant biomass into soil after harvest ${ }^{5}$. Cry $1 \mathrm{Ab}$ toxins were easily adsorbed onto clay-sized fractions, humic acids and soils ${ }^{6-9}$. Main traits of adsorption to clay minerals are a rapid adsorption (0.5-3 h), with optimum $\mathrm{pH}$ between 6 and 8 , mostly non reversible ${ }^{10}$. The adsorption affects protein mobility, bioavailability, degradability and persistence, therefore, some Cry proteins were shown to persist in soil for months following harvest and some to remain insecticidal in soils ${ }^{5,11}$. The toxin was not utilized as a source of carbon or carbon plus nitrogen when bound on montmorillonite and kaolinite homoionic to $\mathrm{Na}$ or clay-size fractions ${ }^{12}$.

Previous studies showed that temperature had no significant influence on the adsorption of Cry1 $\mathrm{Ab}$ toxin ${ }^{13,14}$, therefore, this issue received little attention for a long time. However, recent studies reported that the adsorption of Bt toxin by montmorillonite was endothermic while the adsorption by kaolinite, goethite and silica was exothermic ${ }^{15}$. The characteristics that thermal effects of toxin adsorption changed with minerals attracted attention of researchers. In addition, although several reports investigated the thermodynamics of toxin adsorption on the surface of minerals, the thermodynamic behaviors of toxin adsorption in soil has received little attention. Adsorption thermodynamic behaviors are important factors for evaluating the environmental risk, as this process governs Bt toxin fate and bioavailability. Latosol is a zonal soil distributed in the tropical and subtropical areas. With the large scale cultivation of transgenic crops expressing Bt insecticidal proteins in this region, the problem of environmental safety caused by these Bt crops has received extensive attention ${ }^{16}$. The objectives of this study is to: (1) analyze the influencing laws of temperature on the adsorption of Cry1 Ab toxin in Chinese latosol; (2) obtain the thermodynamic parameters (Gibbs standard free energy $\Delta \mathrm{G}^{0}$, standard enthalpy change $\Delta \mathrm{H}^{0}$, standard entropy change $\Delta S^{0}$ and adsorption energy E). These results can extend our current knowledge on the fate and behavior of Cry1Ab toxin in the tropical and subtropical regions and benefit to evaluate its environmental risk. 


\section{EXPERIMENTAL}

Preparation of the purified Cry1Ab toxin: A genetically modified strain B. thuringiensis subsp. kurstaki HD-1 provided by the State Key Laboratory of Huazhong Agricultural University. The purified Cry $1 \mathrm{Ab}$ toxin was prepared as described by Helassa et al. ${ }^{10}$. The molecular weight of the toxin was 66 $\mathrm{kDa}$ as determined by polyacrylamide gel electrophoresis (SDS-PAGE).

Preparation of soil: The Chinese latosol was sampled from the $0-17 \mathrm{~cm}$ layer of a cultivated land in Leizhou, Guangdong province, China. The air-dried samples were homogenized, crushed and passed through a 100-mesh sieve ${ }^{17}$. Organic matter and cation exchange capacity the specific surface area were determined by $\mathrm{K}_{2} \mathrm{Cr}_{2} \mathrm{O}_{7}$ digestion and extraction with $\mathrm{NH}_{4}$-acetate, respectively ${ }^{18}$. The specific area was determined by the $\mathrm{N}_{2}$ adsorption method using the ST-2000/ST08A instrument (Beijing Analytical Instrument Company). Some properties of soil are listed in Table-1.

\section{TABLE-1}

SOME PROPERTIES OF THE TROPICAL SOIL USED

\begin{tabular}{cccc}
\hline Soil & $\mathrm{OM}\left(\mathrm{g} \mathrm{kg}^{-1}\right)$ & $\mathrm{SSA}\left(\mathrm{m}^{2} \mathrm{~g}^{-1}\right)$ & $\mathrm{CEC}\left(\mathrm{cmol} \mathrm{kg}^{-1}\right)$ \\
\hline Latosol & 21.6 & 35.1 & 18.9 \\
\hline
\end{tabular}

Adsorption thermodynamics: The adsorption isotherms were measured in the range of toxin concentrations from 4.85 $\times 10^{-6}$ to $1.82 \times 10^{-5} \mathrm{~mol} \mathrm{~L}^{-1}$ and soil concentration of $1.0 \mathrm{mg}$ $\mathrm{mL}^{-1}$ at $\mathrm{pH}$ 7.0. The soil-toxin mixtures were shaken at 300 rpm at $5 \pm 1{ }^{\circ} \mathrm{C}, 25 \pm 1{ }^{\circ} \mathrm{C}$ and $45 \pm 1{ }^{\circ} \mathrm{C}$, respectively. After $3 \mathrm{~h}$, the suspension was centrifuged at $20,000 \mathrm{~g}$ for $20 \mathrm{~min}$ and the absorbance of supernatant was measured as indicated previously. The data obtained from the adsorption process are fitted into Langmuir equation ${ }^{19}$.

$$
\mathrm{q}_{\mathrm{e}}=\frac{\mathrm{q}_{\max } \mathrm{bC}_{\mathrm{e}}}{1+\mathrm{bC}_{\mathrm{e}}}
$$

where $\mathrm{q}_{\mathrm{e}}$ is the amount of adsorption at equilibrium, mol g-1. $\mathrm{q}_{\max }$ is the maximum adsorption capacity, mol $\mathrm{g}^{-1} ; \mathrm{C}_{\mathrm{e}}$ is the equilibrium concentration of toxin in the bulk solution, mol $\mathrm{L}^{-1}$; $\mathrm{b}$ is the constant related to the energy of adsorption $\left(\mathrm{L} \mathrm{mol}^{-1}\right)$.

The essential feature of the Langmuir isotherm can be expressed by means of $\mathrm{R}_{\mathrm{L}}$, a dimensionless constant referred to as the separation factor or the equilibrium parameter. $\mathrm{R}_{\mathrm{L}}$ is calculated using the following equation ${ }^{20}$ :

$$
\mathrm{R}_{\mathrm{L}}=\frac{1}{1+\mathrm{bC}_{0}}
$$

where $\mathrm{C}_{0}$ is the initial Cry $1 \mathrm{Ab}$ toxin concentration, $\mathrm{mol} \mathrm{L}^{-1}$.

Thermodynamic parameters such as Gibbs free energy $\left(\Delta \mathrm{G}^{0}\right)$, standard enthalpy change $\left(\Delta \mathrm{H}^{0}\right)$ and standard entropy change $\left(\Delta S^{0}\right)$ for the process were calculated using the equations $^{21,22}$ :

$$
\begin{gathered}
\Delta \mathrm{G}^{0}=-\mathrm{RT} \ln \mathrm{K}_{\mathrm{ads}}=-\mathrm{RT} \ln (55.5 \mathrm{~b}) \\
\ln \mathrm{K}_{\mathrm{ads}}=-\frac{\Delta \mathrm{H}^{0}}{\mathrm{RT}}+\frac{\Delta \mathrm{S}^{0}}{\mathrm{R}}
\end{gathered}
$$

where $\Delta G^{0}$ is the standard free energy changes of the adsorption processes, $\mathrm{J} \mathrm{mol}^{-1}$; $\mathrm{R}$ is the universal gas constant, 8.314 $\mathrm{J} \mathrm{mol}^{-1} \mathrm{~K}^{-1}$; T is the absolute temperature, $\mathrm{K} ; \mathrm{K}_{\mathrm{ads}}$ is equilibrium constant of the adsorption processes, dimensionless; 55.5 is the molecular weight of water, mol L-1; $\Delta \mathrm{H}_{0}$ is the standard enthalpy changes of the adsorption processes, $\mathrm{J} \mathrm{mol}^{-1} ; \Delta \mathrm{S}_{0}$ is the standard entropy changes of the adsorption processes, $\mathrm{J} \mathrm{mol}^{-1} \mathrm{~K}^{-1}$.

Energy of adsorption: The mean energy of Cry $1 \mathrm{Ab}$ toxin adsorption can be calculated by eqn. $(5)^{23}$ :

$$
\mathrm{E}=\frac{1}{\sqrt{-2 \mathrm{~K}_{\mathrm{E}}}}
$$

where $\mathrm{E}$ is the mean energy of adsorption, $\mathrm{J} \mathrm{mol}^{-1}$; $\mathrm{K}_{\mathrm{E}}$ (negative value) is the parameter related to the adsorption energy, $\mathrm{mol}^{2} \mathrm{~J}^{-2}$, it can be calculated by the linear form of DubininRadushkevic (D-R) equation:

$$
\ln \mathrm{q}_{\mathrm{e}}=\ln \mathrm{q}_{\max }-\mathrm{K}_{\mathrm{E}} \varepsilon^{2}
$$

where $\varepsilon$ is the Polanyi potential, $\varepsilon=R T \ln \left(1+1 / C_{e}\right), \mathrm{J} \mathrm{mol}^{-1}$.

Analysis of transmission electron microscope: Before and after adsorption of Cry1 Ab toxin, particles of latosol were dispersed in the water. Soil suspension was coated on the copper wire. After air drying, the particles of latosol were detected by TEM (H-600, Hitachi Ltd., Japan).

Statistics: Data are expressed as the means \pm the standard errors of the means ( \pm SEMs). Unless indicated otherwise, the SEMs are within the dimensions of the figure symbols.

\section{RESULTS AND DISCUSSION}

Adsorption isotherms: The adsorption isotherm is the equilibrium relationship between the concentration in solution and concentration in the adsorbent surface at a given temperature. As shown in Fig. 1, the adsorption isotherms of Cry1 Ab toxin followed Langmuir equation $\left(\mathrm{R}^{2}>0.98\right)$, the curves is of the L-type with an initial steep rise in uptake followed by a gradual increase to a more or less flat plateau at 283, 298 and $313 \mathrm{~K}$. The adsorption rose faster at high temperature than at low temperature. The maximum adsorption amount $\mathrm{q}_{\max }$ of the toxin by latosol at three temperatures was $4.50 \times 10^{-6}, 5.99 \times 10^{-6}$ and $7.55 \times 10^{-6} \mathrm{~mol} \mathrm{~g}^{-1}$, respectively (Table-2).

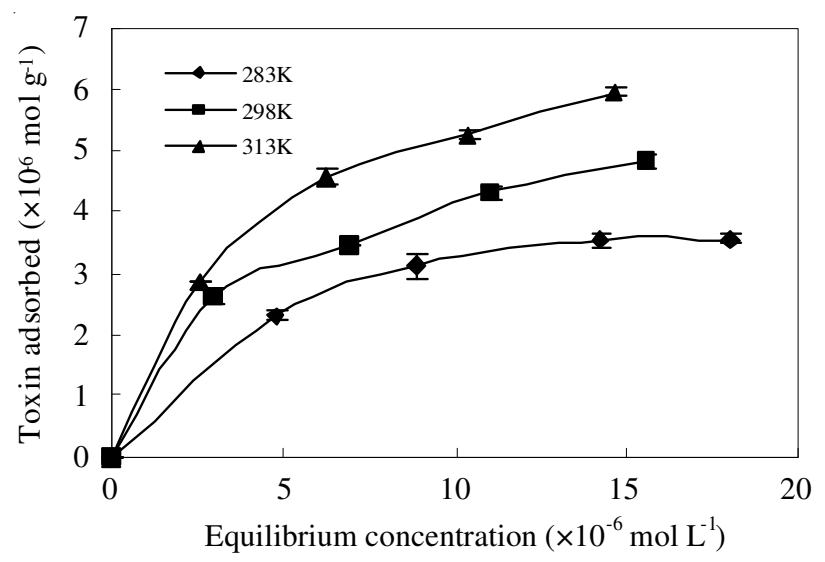

Fig. 1. Adsorption isotherm of the Cry1 Ab toxin by latosol

\begin{tabular}{ccccc} 
TABLE- 2 \\
LANGMUIR PARAMETERS FOR THE \\
ADSORPTION OF THE Cry 1Ab TOXIN \\
\hline Temperature $(\mathrm{K})$ & $\mathrm{b}\left(\mathrm{L} \mathrm{mol}^{-1}\right)$ & $\mathrm{K}_{\text {ads }}$ & $\mathrm{q}_{\max }\left(\mathrm{mol} \mathrm{g}^{-1}\right)$ & $\mathrm{R}^{2}$ \\
\hline 283 & $2.35 \times 10^{5}$ & $1.31 \times 10^{7}$ & $4.50 \times 10^{-6}$ & 0.9970 \\
298 & $2.34 \times 10^{5}$ & $1.30 \times 10^{7}$ & $5.99 \times 10^{-6}$ & 0.9891 \\
313 & $2.40 \times 10^{5}$ & $1.33 \times 10^{7}$ & $7.55 \times 10^{-6}$ & 0.9987 \\
\hline
\end{tabular}


The effect of the isotherm shape has been discussed with a view to predict whether an adsorption system is favorable or unfavorable. The value of $\mathrm{R}_{\mathrm{L}}$ indicates the type of the isotherm to be either unfavorable $\left(R_{L}>1\right),\left(R_{L}=0\right)$. Values of $R_{L}$ were shown in Table-3.

\begin{tabular}{ccc}
\multicolumn{4}{c}{ TABLE-3 } \\
\multicolumn{3}{c}{$\begin{array}{c}\text { SEPARATION FACTOR CONSTANT OF Cry1 Ab } \\
\text { TOXIN ADSORBED BY LATOSOL }\end{array}$} \\
\hline $\begin{array}{c}\text { Temperature } \\
(\mathrm{K})\end{array}$ & $\begin{array}{c}\text { Initial concentration } \\
\text { of Bt toxin }\left(\mathrm{mol} \mathrm{L}^{-1}\right)\end{array}$ & $\begin{array}{c}\text { Separation factor } \\
\left(\mathrm{R}_{\mathrm{L}}\right)\end{array}$ \\
\hline \multirow{2}{*}{283} & $4.848 \times 10^{-6}$ & 0.4672 \\
& $9.091 \times 10^{-6}$ & 0.3187 \\
& $14.39 \times 10^{-6}$ & 0.2280 \\
& $18.18 \times 10^{-6}$ & 0.1895 \\
\hline \multirow{2}{*}{298} & $4.848 \times 10^{-6}$ & 0.4682 \\
& $9.091 \times 10^{-6}$ & 0.3095 \\
& $14.39 \times 10^{-6}$ & 0.2287 \\
& $18.18 \times 10^{-6}$ & 0.1901 \\
\hline \multirow{2}{*}{313} & $4.848 \times 10^{-6}$ & 0.4623 \\
& $9.091 \times 10^{-6}$ & 0.3144 \\
& $14.39 \times 10^{-6}$ & 0.2246 \\
& $18.18 \times 10^{-6}$ & 0.1865 \\
\hline
\end{tabular}

The variations of the separation factor $\left(\mathrm{R}_{\mathrm{L}}\right)$ of Cry1 $\mathrm{Ab}$ toxin adsorption by latosol ranged from 0.1865 to 0.4682 (Table-3), which indicated that the Cry1 Ab toxin was favourably adsorbed by tropic soil. The $\mathrm{R}_{\mathrm{L}}$ values decreased as the initial concentration of $\mathrm{Bt}$ toxin increased, but minor changes of $\mathrm{R}_{\mathrm{L}}$ were observed between 283 and $313 \mathrm{~K}$ at a fixed toxin initial concentration.

Adsorption thermodynamic parameters: The thermodynamic parameters of Cry $1 \mathrm{Ab}$ toxin adsorbed by latosol are shown in Table-4.

TABLE- 4

THERMODYNAMIC PARAMETERS OF CRY1AB TOXIN ADSORBED BY TROPICAL SOIL

\begin{tabular}{cccc}
\hline Temperature $(\mathrm{K})$ & $\Delta \mathrm{G}^{0}\left(\mathrm{~kJ} \mathrm{~mol}^{-1}\right)$ & $\Delta \mathrm{H}^{0}\left(\mathrm{~kJ} \mathrm{~mol}^{-1}\right)$ & $\Delta \mathrm{S}^{0}\left(\mathrm{~J} \mathrm{~mol}^{-1}\right)$ \\
\hline 283 & -38.55 & & \\
298 & -40.58 & 0.4740 & 137.9 \\
313 & -42.69 & & \\
\hline
\end{tabular}

Gibbs free energy $\left(\Delta \mathrm{G}^{0}\right)$ of the toxin adsorbed by latosol ranged from -38.55 to $-42.69 \mathrm{~kJ} \mathrm{~mol}^{-1}$. In general, the adsorption belongs to chemical process when the $\Delta \mathrm{G}^{0}$ is more than 40 $\mathrm{kJ} \mathrm{mol}^{-1}$. The negative values of the adsorption $\Delta \mathrm{G}^{0}$ by latosol indicated that Cry $1 \mathrm{Ab}$ toxin adsorption occurred via a spontaneous process, implying that changes in the protein structure favor the adsorption process ${ }^{24}$. The values of $\Delta G^{0}$ increased with the increase of temperature, indicating that the adsorption had higher spontaneous trend at high than low temperature. The Langmuir isotherm equation has been widely used in adsorption process. However, the theoretical sense of the concentration of adsorbate in the Langmuir equation is usually paid little attention. $\mathrm{Liu}^{25}$ pointed out that the concentration of adsorbate used in Langmuir isotherm equation must be expressed as its molar concentration, otherwise, it would eventually leads to misapplication of the Langmuir isotherm sequation in calculation of the change in standard free energy $\left(\Delta \mathrm{G}^{0}\right)$ of adsorption. In our studies, the concentration of
Cry $1 \mathrm{Ab}$ toxin was mol L-1 and the exchange adsorption between adsorbate and dissolvent was also considered.

The adsorption of protein onto adsorbent-solution interface can be denoted as a substitutional adsorption process between the protein molecules in the aqueous solution (Protein(sol)) and the water molecules on the adsorbent surface $\left[\mathrm{H}_{2} \mathrm{O}_{(\mathrm{ads})}\right]^{21,22,26}$ :

Protein $_{(\text {sol })}+\mathrm{XH}_{2} \mathrm{O}_{(\text {ads })} \rightleftharpoons \operatorname{Protein}_{(\text {ads })}+\mathrm{XH}_{2} \mathrm{O}_{(\text {sol })}$ (7)

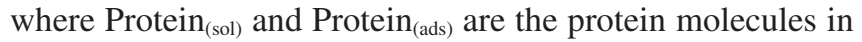
the aqueous solution and adsorbed on the mineral surface, respectively; $\mathrm{H}_{2} \mathrm{O}_{\text {(sol) }}$ and $\mathrm{H}_{2} \mathrm{O}_{\text {(ads) }}$ are the water molecules in the aqueous solution and adsorbed on the mineral surface, respectively; $\mathrm{X}$ is the size ratio representing the number of water molecules replaced by one molecule of protein.

The equilibrium constant $\mathrm{K}_{\mathrm{ads}}$ (dimensionless) is not equal to the parameter ' $b$ ' from Langmuir equation. The ' $b$ ' in Langmuir equation is not a dimensionless parameter where as its dimension is the reciprocal of solute concentration. According to the previsions of IUPAC (International Union of Pure and Applied Chemistry), the standard equilibrium constant for calculating the $\Delta \mathrm{G}^{0}$ must be dimensionless ${ }^{27}$.

The relationship between $\mathrm{K}_{\mathrm{ads}}$ and ' $\mathrm{b}$ ' for the liquid-solid adsorption process in dilute solution is expressed as follows ${ }^{27,28}$ :

$$
\mathrm{K}_{\mathrm{ads}}=\mathrm{b} \times \mathrm{a}_{\mathrm{H}_{2} \mathrm{O}}^{\mathrm{sol}}
$$

where $\mathrm{a}_{\mathrm{H}_{2} \mathrm{O}}^{\mathrm{sol}}$ is the water activity in solution. If the solution is dilute and the adsorbed phase is an ideal solution, the activity of water $\left(\mathrm{a}_{\mathrm{H}_{2} \mathrm{O}}^{\mathrm{sol}}\right)$ in solution can be replaced by its mole concentration $(55.5 \mathrm{~mol} / \mathrm{L})^{21,22,29}$. Thus

$$
\mathrm{K}_{\mathrm{ads}}=55.5 \mathrm{~b}
$$

The $\Delta \mathrm{H}^{0}$ of Cry $1 \mathrm{Ab}$ toxin adsorbed by tropical soil was $0.4740 \mathrm{~kJ} \mathrm{~mol}^{-1}$ (Table-4). The positive sign of $\Delta \mathrm{H}^{0}$ indicated that the adsorption of toxin on tropical soil was endothermic, favorable adsorption would occur at higher temperature. Fu ${ }^{15}$ reported that the adsorption of Cry1 $\mathrm{Ab}$ toxin by montmorillonite was endothermic $\left(\Delta \mathrm{H}^{0}=9.0 \mathrm{~kJ} \mathrm{~mol}^{-1}\right)$ while by kaolinite, goethite and silica was exothermic. Zhou et al. ${ }^{26}$ verified that the adsorption of Cry1 Ab toxin by montmorillonite, kaolinite and silica was exothermic and the adsorption amount increased with the decreasing temperature. Helassa et $a l^{30}$, however, observed that the adsorption affinity of Cry $1 \mathrm{Ab}$ protein in soil was less at lower temperature, which was consistent with our results. The interaction between the toxin and soils probably ascribed to hydrophobic affinity ${ }^{30,31}$, clay minerals are usually considered to be hydrophilic surfaces and soil organic matter may considerably enhance hydrophobicity leading to macroscopic changes in soil properties, therefore, Cry1 Ab toxin variety, soil type and soil organic matter may affect the adsorption of Cry1Ab toxin in soil.

The $\Delta \mathrm{S}^{0}$ of toxin adsorbed by latosol was $137.9 \mathrm{~J} \mathrm{~mol}^{-1} \mathrm{~K}^{-1}$ (Table-4). The positive sign of $\Delta S^{0}$ indicated that the freedom increased when the toxin adsorbed by latosol, suggesting that the entropy was the driving forces for adsorption ${ }^{32,33}$. As the molecular volume of water is very small compared to Bt protein, the adsorption of one mole protein result in the desorption of dual mole water, therefore, mutual penetration of hydration layer causing disordering of the water, following the increase of entropy. 
Energy of Cry1Ab toxin adsorption: The relationship between $\ln \mathrm{q}_{\mathrm{e}}$ and $\varepsilon^{2}$ during the adsorption of Cry1 $\mathrm{Ab}$ toxin by tropical soil was shown in Fig. 2 .

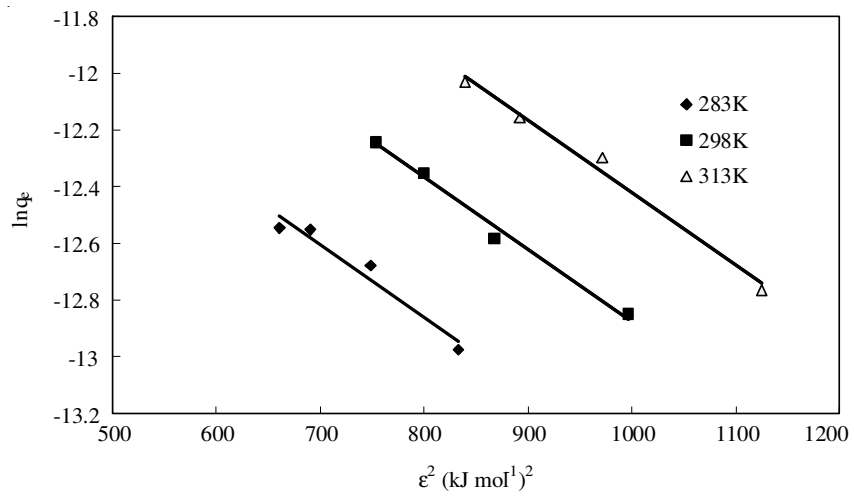

Fig. 2. Relationship between $\ln \mathrm{q}_{\mathrm{e}}$ and $\varepsilon^{2}$ during the adsorption of Cry $1 \mathrm{Ab}$ toxin by latosol

The mean energy of Cry $1 \mathrm{Ab}$ toxin adsorption at $283 \mathrm{~K}$, $298 \mathrm{~K}$ and $313 \mathrm{~K}$ was $13.92,14.04$ and $13.98 \mathrm{~kJ} \mathrm{~mol}^{-1}$, respectively. The magnitude of $\mathrm{E}$ is useful for estimating the type of sorption reaction, i.e., an energy ranged from 8 to $16 \mathrm{~kJ} \mathrm{~mol}^{-1}$ indicated an ion-exchange reaction. The above results suggested that the adsorption of Cry1 Ab toxin in latosol belong to ionexchange process.

Analysis of TEM: The size of latosol particles which are fully dispersed in the water ranged from 100 to $400 \mathrm{~nm}$ (Fig. 3). There is no significant change before and after adsorption of Cry1Ab toxin.

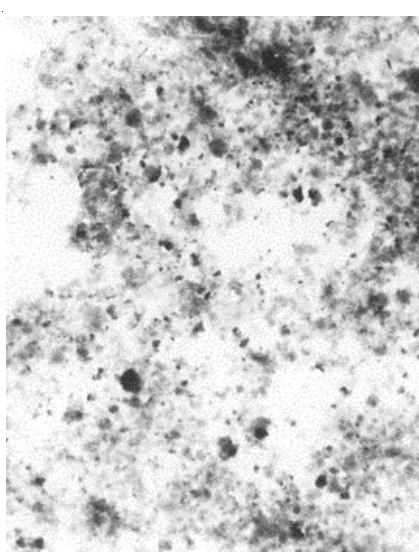

(a )Before adsorption of toxin

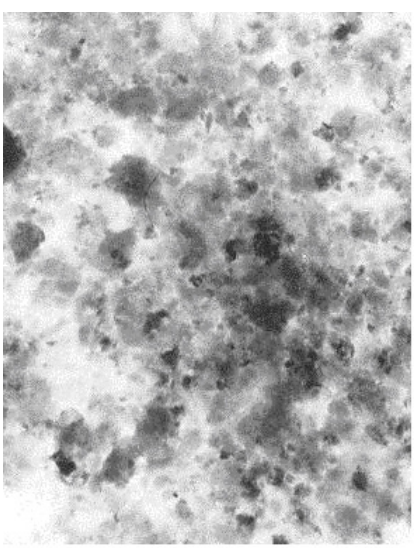

(b )After adsorption of toxin
Fig. 3. TEM images of latosol particles before and after adsorption of toxin

\section{Conclusion}

The adsorption isotherms of Cry1 Ab toxin followed Langmuir equation $\left(\mathrm{R}^{2}>0.98\right)$ and the curves belonged to $\mathrm{L}$ type. The adsorption increased with the increased temperature between 283 and $313 \mathrm{~K}$, suggesting that the environmental risk of Cry $1 \mathrm{Ab}$ toxin in latosol probably enhances if temperature increases. The adsorption of the Cry $1 \mathrm{Ab}$ toxin by latosol was a spontaneous, endothermic, entropy-increasing and favourable process. The separation factor $\mathrm{R}_{\mathrm{L}}$ ranged from 0.1865 to 0.4682 , indicating that the adsorption of Cry $1 \mathrm{Ab}$ toxin in latosol was favourable. The adsorption energy for Cry $1 \mathrm{Ab}$ toxin ranged from 8 to $16 \mathrm{~kJ} \mathrm{~mol}^{-1}$, indicating that it was an ion-exchange mechanism.

\section{ACKNOWLEDGEMENTS}

The research was funded by the National Natural Science Foundation of China (No. 31070478), the Natural Science Foundation of Tianjin, China (No. 08JCZDJC18800) and the Research Program of Tianjin Agricultural University (No. 2008D016).

\section{REFERENCES}

1. M. Sander, M. Mandliger and R.P. Schwarzenbach, Environ. Sci. Technol., 44, 8870 (2010).

2. I. Icoz and G. Stotzky, Soil Biol. Biochem., 40, 559 (2008).

3. D. Saxena, S. Flores and G. Stotzky, Soil Biol. Biochem., 34, 133 (2002).

4. D. Saxena and G. Stotzky, Nat. Biotechnol., 19, 199 (2001).

5. G. Stotzky, J. Environ., Quality, 29, 691 (2000).

6. G. Stotzky, Plant Soil, 266, 77 (2004).

7. J. Wang, S. Luo and Y. Feng, Acta Ecologyca Sinica, 23, 797 (2003).

8. T. Chevallier, P. Muchaoneyerwa and C. Chenu, Soil Biol. Biochem., 35, 1211 (2003).

9. H. Tapp and G. Stotzky, Soil Biol. Biochem., 30, 471 (1998).

10. N. Helassa, H. Quiquampoix, S. Noinville, W. Szponarski and S. Staunton, Soil Biol. Biochem., 41, 498 (2009).

11. D.W. Hopkins and E.G. Gregorich, Eur. J. Soil Sci., 54, 793 (2003).

12. J. Koskela and G. Stotzky, Appl. Environ. Microbiol., 63, 3561 (1997).

13. X. Zhou, Q. Huang, S. Chen and Z. Yu, Appl. Clay Sci., 30, 87 (2005).

14. G. Venkateswerlu and G. Stotzky, Current Microbiol., 25, 225 (1992).

15. Q. Fu, Y. Deng, H. Li, J. Liu, H. Hu, S. Chen and T. Sa, Appl. Surf. Sci., 255, 4551 (2009).

16. B. Sarkar, A.K. Patra, T.J. Purakayastha and M. Megharaj, Environ. Monitor. Assess., 156, 595 (2009).

17. P. Cai, Q. Huang, D. Jiang, X. Rong and W. Liang, Colloids Surf. B, 49, 49 (2006).

18. Y. Xiong, Soil Colloids, Science Press, Beijing, China vol. 2 (1985).

19. E.I. Unuabonah, K.O. Adebowale, B.I. Olu-Owolabi, L.Z. Yang and L.X. Kong, Hydrometallurgy, 93, 1 (2008).

20. H. Zaghouane-Boudiaf and M. Boutahala, J. Chem. Eng., 170, 120 (2011).

21. M.A. Shaker and H.H. Abdel-Rahman, J. Am. Appl. Sci., 4, 554 (2007).

22. F. Bentiss, M. Lebrini and M. Lagrenée, Corrosion Sci., 47, 2915 (2005).

23. L. Zhang, Y. Zhu, H. Li, N. Liu, X. Liu and X. Guo, Rare Metals, 29, 16 (2010).

24. N. Willem, Adv. Colloid Interf. Sci., 25, 267 (1986)

25. Y. Liu, Eng. Aspects, 274, 34 (2006).

26. X. Zhou, N. Liu, J. Gao and M. Zhang, J. Int. Chem. React. Eng., 9, A5 (2011).

27. International Union of Pure and Applied Chemistry Physical Chemistry Division, Quantities, Units and Symbols in Physical Chemistry, Blackwell Science Ltd, London, edn 2 (1993).

28. Z. Tao and T. Chu, J. Colloid Interf. Sci., 231, 8 (2000).

29. L.B. Tang, G.N. Mu and G.H. Liu, Corrosion Sci., 45, 2251 (2003).

30. N. Helassa, A. M'Charek, H. Quiquampoix, S. Noinville, P. Déjardin, R. Frutos and S. Staunton, Soil Biol. Biochem., 43, 1089 (2011).

31. X. Zhou, J. Gao, Q. Huang and J. Xiong, J. Int. Chem. React. Eng., 8, A20 (2010) .

32. P.D. Ross and S. Subramanian, Biochemsitry, 20, 3096 (1981)

33. S.H. Lee and E. Ruckenstein, J. Colloid Interf. Sci., 125, 365 (1988). 